\title{
Yield of three papaya genotypes and their tolerance to papaya ringspot virus in Puerto Rico'
}

\author{
Jaime Escudero", Alvaro Acosta ${ }^{3}$, Lucas V. Ramírez, \\ Isabel B. Caloni ${ }^{5}$ and Gerardo Ruiz Sifre ${ }^{6}$
}

\begin{abstract}
Papaya cultivars 'Cariflora', 'Sunrise Solo' and the $F$, hybrid Cariflora $x$ Sunrise Solo were inoculated and evaluated for papaya ringspot virus (PRV) in southern Puerto Rico. High tolerance to PRV was observed in papaya cultivars Cariflora and the $F$, hybrid Cariflora $x$ Sunrise Solo. Chemical analysis of the fruit showed that Brix values increased as the fruit changed from green to yellow in both Cariflora and the $F$, hybrids; the $\mathrm{pH}$ of the fruit, however, remained constant. Marketable yield of the $F$, hybrid was $52,500 \mathrm{~kg} / \mathrm{ha}$ followed by that of Cariflora, with $42,000 \mathrm{~kg} / \mathrm{ha}$ and Sunrise Solo with 35,500 $\mathrm{kg} / \mathrm{ha}$. Fruit weights of Cariflora and $F$, hybrid were significantly higher than

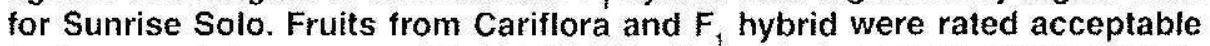
in flavor and appearance. Virus identification was based on symptomatology, host range insect transmission, viral inclusions, and serology. Cultivar Cariflora and the $F$, hybrid Cariflora $x$ Sunrise Solo are potentially suitable for commercial production in Puerto Rico.
\end{abstract}

\section{RESUMEN}

Producción de tres genotipos de papaya y su tolerance al virus del anulado de la papaya en puerto rico

Los cultivares de papaya (Carica papaya L.) 'Cariflora', 'Sunrise Solo' y el $F_{1}$ del hibrido Cariflora $x$ Sunrise Solo se inocularon y evaluaron en términos de su tolerancia al virus del anulado de la papaya (VAP) en el sur de Puerto Rico. Las variedades Cariflora y el hibrido Cariflora $x$ Sunrise Solo mostraron ser altamente tolerantes al VAP. Los valores de Brix de la fruta aumentaron a medida que ésta cambió de verde a amarilla; el $\mathrm{pH}$, por el contrario, se mantuvo constante. La producción comercial del híbrido fue de $52,000 \mathrm{~kg} / \mathrm{ha}$, seguida por la de Cariflora con $42,000 \mathrm{~kg} / \mathrm{ha}$ y la de Sunrise Solo con $32,500 \mathrm{~kg} / \mathrm{ha}$. El peso medio de la fruta de Cariflora y del híbrido fue significativamente más alto que el de Sunrise Solo. La papaya Cariflora y el hibrido fueron aceptables en cuanto a sabor y color de la pulpa al evaluarlas un panel de catadores. El virus se identificó mediante la sintomatología de campo, los sintomas en plantas diferenciales, la transmisión por insectos, la presencia de inclusiones virales y la serología. La variedad Cariflora y el híbrido Cariflora $x$ Sunrise Solo tienen potencial para producirse comercialmente en Puerto Rico.

'Manuscript submitted to Editorial Board 19 May 1992.

2Research Assuciate, Department of Crop Protection.

"Research Technician, Department of Horticulture.

'Assistant Researcher, Department of Horticulture.

${ }^{5}$ Food Technologist, Laboratory of Food Technology.

"Assistant Researcher, Department of Horticulture. 


\section{INTRODUCTION}

In Puerto Rico, papaya is primarily sold as fresh fruit for hotels, restaurants and household markets; processed papaya products are also in demand by the local consumer. It is also exported to the United States and Europe as fresh fruit (14). Commercial production of papaya has been gradually increasing on the island. It reached nearly 5,000 tons with a value of $\$ 1.6$ million in 1990 (8). The local and international demand for papaya is also increasing at a rapid pace.

Heavy crop losses have been attributed to viral diseases $(7,15)$. In 1978, Rodríguez (17) reported that two different mosaic diseases affecting papaya in Puerto Rico were strains of the same virus and were also related to the papaya ringspot virus (PRV). PRV is currently one of the most destructive diseases of C. papaya (5). Results of surveys conducted in Ponce, Santa Isabel, Guánica, Naranjito, Canóvanas, Río Grande, Gurabo, and Isabela from 1982 to 1988 confirm earlier reports (17) that the incidence of PRV is very high. Effects of the local PRV on papaya yields were severe. A highly productive Solo papaya planting in the Ponce Region, normally having a 3-year lifespan (2), was totally destroyed by PRV (with nearly $100 \%$ infection) within 2 years.

Papaya ringspot virus has been reported to limit papaya production in Hawaii (10), Florida (4), the Dominican Republic (19), South America (10), Africa (11), Australia (15), the Far East (13), India (18), and Taiwan (20). The virus, which has been classified in the potyvirus group (15), is not seed-borne but transmitted by a number of aphid species in a non-persistent manner $(17,11)$. Host range of PRV is limited to the Caricaceae, Cucurbitaceae, and Chenopodiaceae families (14).

Few papaya cultivars have been developed with tolerance to PRV. Cariflora cultivar was derived by polycrossing several offspring of dioecious seed line accessions that originated in a commercial papaya planting in South Florida (6). Also Cariflora and Sunrise Solo male and female plants were obtained from papaya breeding. The $F_{1}$ hybrid was developed by the USDA Tropical Agricultural Research Station (TARS) in Isabela, Puerto Rico. This hybrid was obtained from open pollinated seeds developed by inbreeding among Sunrise Solo and Cariflora descendent.

The purpose of this study was to evaluate two new papaya genotypes: Cariflora and the cross Cariflora $x$ Sunrise ( $F_{1}$ hybrid), and compare them with the commercial cultivar Sunrise Solo in terms of PRV tolerance, production, and product characteristics. 


\section{MATERLAIS AND METHODS}

Field trials. The papaya orchard was established as a completely randomized split plot with four replications at AES Juana Diaz in August 1989. Whole plots consisted of two treatments (PRV inoculated and non-inoculated plants) and the subplots of three papaya genotypes [Cariflora, Cariflora $x$ Sunrise Solo $\left(\mathrm{F}_{1}\right)$ and Sunrise Solo]. Seed from each cultivar were obtained from AES Isabela. For each treatment combination, eight plants were planted at $1.8 \mathrm{~m}$ between plants and $1.8 \mathrm{~m}$ between rows, for an equivalent plant density of 2,032 plants per hectare. The soil at the Juana Díaz substation is a San Antón clay loam with $\mathrm{pH} 7.2$. Gray polyethylene mulch $(1.2 \mathrm{~m}$ wide and $0,050 \mathrm{~mm}$ thick) underlaid with drip irrigation lines (placed on the soil surface at the center of each row) was installed before transplanting. Emitters were $1.8 \mathrm{~m}$ apart with a flow rate of $3.8 \mathrm{liter} / \mathrm{h} / \mathrm{m}$, respectively.

Fertilizer was applied through fertigation at the beginning of each trial $800 \mathrm{~kg} / \mathrm{ha} \mathrm{NH}_{4} \mathrm{NO}_{3}$ and $600 \mathrm{~kg} / \mathrm{ha} \mathrm{KNO}_{3}$. After transplanting, weeds were controlled with Gramoxone, then by hand weeding as required.

Virus inoculation. The virus inoculum was collected from a commercial papaya field in Canóvanas June 1990. PRV-affected papaya leaves were triturated with a sterile mortar and pestle in $0.01 \mathrm{M} \mathrm{K}_{2} \mathrm{PO}_{4}$ buffer $(1: 10 \mathrm{w} / \mathrm{v}, \mathrm{pH}$ 7.0) (11). The sap was rubbed on carborundum $(400$ mesh)-dusted leaves on 68 virus-free papaya seedlings of each cultivar. Inoculated plants and healthy controls were kept in an insect proof greenhouse at an average temperature of $30^{\circ} \mathrm{C}$ and observed for 21 days. Three weeks after inoculation, test cultivars and healthy controls were transplanted to the field.

To reduce damage by insect and mites, Malathion 25\% WP (4.6 kg/ ha), Vendex (.28 kg/ha) and Sulfur ( $4.6 \mathrm{~kg} / \mathrm{ha}$ ) were sprayed at weekly intervals. The fungicides Mansate and Kocide were also sprayed weekly at a rate of $2.2 \mathrm{~kg} / \mathrm{ha}$ as a preventive measure.

Field plots were harvested 48 times from February 1989 to February 1990. For each harvested plot, marketable fruit yield and number of fruits were recorded. Average fruit length, diameter, and weight were determined from plot samples.

Chemical characteristics and sensory evaluation of fruits. Fruit samples, harvested green or when showing some color change (breaker stage or beyond), were taken to the Food Technology Laboratory for physicochemical analysis. Ripeness, Brix, $\mathrm{pH}$, acidity, color, and texture of composite samples from half of each fruit were determined. The 
other half was used for sensory evaluation. Papaya samples were compared with the Hunter Color Index to measure the effect of color changes on three simultaneous parameters ( $\mathrm{L}$, $\mathrm{a}$ and $\mathrm{b}$ ).

Sliced fruits were appraised individually in terms of appearance and flavor by a taste panel using $+2,-2$ scale (12). Preference by panelists was also measured.

Virus host range. In this study, papaya infected with PRV was also identified. Papaya leaves with PRV symptoms from each cultivar were triturated in $0.01 \mathrm{M}$ potassium phosphate buffer (1:10 weight/volume, pH 7.0) with sterile mortar and pestle (11). The homogenate was pressed through two layers of cheesecloth, and carborundum $(400$ mesh) was then added to the filtrate. The virus suspension was rubbed onto virus-free test seedlings of Chenopodium quinoa Willd., Cucumis melo L. var Honey Dew, Citrulus lanatus (Thunb) cv Jubilee, Luffa aegyptiaca Miller and Carica papaya L. cv. Sunrise. Inoculated seedlings and the same number of healthy controls were kept in a greenhouse at a temperature of $28^{\circ} \mathrm{C}$ and observed for 21 days.

Insect transmission. The aphid Aphis citricola van $\operatorname{der} \operatorname{Goot}(=A$. spiraecola Patch) was tested as a possible vector of the virus. The insects were obtained from virus-free colonies reared on disease-free Polyscias quilfoley (Bull) Bailey. Apterous aphids were starved for 15 min and allowed to feed on affected papaya leaves for about 10 to 20 min. For inoculation, 10 to 15 viruliferous aphids were used per test plant. The insects were transported on infected leaf sections and the colonized sections placed on the top of the new growth of test plants. For virus transmission with aphids, 10 virus-free papaya seedlings and an equal number of healthy controls were used. The aphids were allowed to remain on the test plants for $24 \mathrm{~h}$ and then killed with a cormmercial pyrethrin spray. Inoculated plants and healthy controls were placed separately in insect proof cages in the greenhouse for observation (21 days).

Light microscopy. Epidermal leaf strips of affected papaya were stained with Calcomine Orange/'Luxol' brilliant green as described by Christie and Edwardson (3), then examined by light microscopy to detect virus-inducted inclusions.

Serology. Sodium dodecyl sulfate (SDS) immunodiffusion tests were carried out as described by Purcifull and Batchelor (16). Crude extracts of papaya leaves with PRV symptoms in $1.5 \%$ SDS were compared with antigen and antisera of PRV isolate from Florida. Normal sera and healthy controls were used routinely through the experiment. 


\section{RESULTS AND DISCUSSION}

Field Evaluation. The $\mathrm{F}_{1}$ hybrid Cariflora $\mathrm{x}$ Sunrise Solo had the highest yields $(52,500 \mathrm{~kg} / \mathrm{ha}$ ) and the highest fruit weight $(786 \mathrm{~g})$ among the three cultivars (table 1). High tolerance for PRV was observed the Cariflora and $\mathrm{F}_{1}$ hybrid cultivars (fig. $1 \mathrm{~A}$ and $1 \mathrm{~B}$ ). The plants recovered from virus symptoms 6 weeks after transplanting. Inoculated plants from both cultivars were comparable to non-inoculated plants in size, flowering, and fruit setting frequency. Ninety percent of the infected Cariflora female plants and $70 \%$ of the $F_{1}$ hybrid did not develop ringspot (fig. 2A).

Almost $100 \%$ of the PRV-inoculated Sunrise did not recover from the disease. Infected plants developed severe foliar mosaic and in some cases plants became badly stunted (fig. 1C). Petioles of infected plants were abnormally short, and leaf laminae were deformed and constricted around the veins, resulting in a shoestring appearance. The fruits of all affected plants developed ringspot (fig. 2B) and often were small with various types of malformations. As a consequence of this severe virus infection on Sunrise Solo, yield was greatly reduced.

TABLE 1.-Marketable yield, total fruit number and mean fruit weight of three papaya cultivars'.

\begin{tabular}{|c|c|c|c|}
\hline Cultivars & $\begin{array}{c}\text { Marketable } \\
\text { yield } d^{2}\end{array}$ & $\begin{array}{l}\text { Total } \\
\text { fruit: }\end{array}$ & $\begin{array}{c}\text { Mean fruit } \\
\text { weight }{ }^{2}\end{array}$ \\
\hline & $\mathrm{kg} / \mathrm{ha}$ & Number & $g$ \\
\hline Cariflora & $42,000 \mathrm{a}$ & $61,875 \mathrm{~b}$ & $727 \mathrm{a}$ \\
\hline Inoculated & 41,250 & 57,000 & 686 \\
\hline Control & 42,750 & 66,750 & 763 \\
\hline Cariflora $\times$ Solo $F_{1}$ & 52,500 a & $70,312 \mathrm{~b}$ & $786 a$ \\
\hline Inoculated & 41,250 & 55,687 & 709 \\
\hline Control & 58,500 & 84,937 & 863 \\
\hline Sunrise-Solo & $37,500 \mathrm{a}$ & $150,750 \mathrm{a}$ & $318 \mathrm{~b}$ \\
\hline Inoculated & 37,500 & 152,625 & 263 \\
\hline Control & 37,500 & 148,687 & 372 \\
\hline
\end{tabular}

'Field plots were harvested 48 times (Feb. 1989 - Feb. 1990).

${ }^{2}$ Based on data obtained from four replications of eight plants each. The production values obtained in this experiment do not necessarily agree with those reported for commercial planting.

"Equivalent density of plants per hectare.

the ratio male to female was 3 to 7 .

-Means in columns followed by same letter do not differ significantly at $\mathrm{P}=0.05$ probability level according to Duncan's multiple range test. 


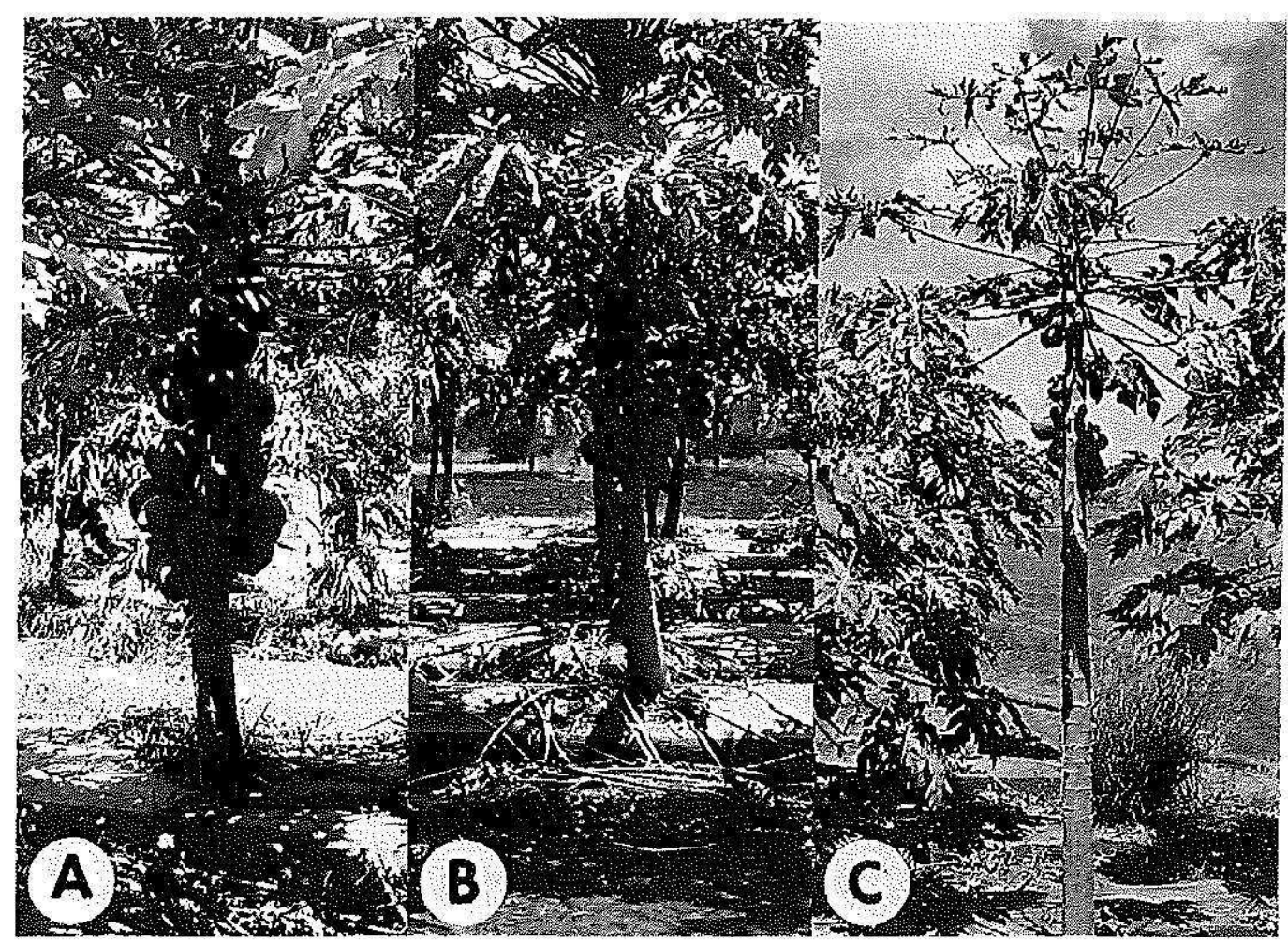

Flg. 1. Papaya plants inoculated with papaya ringspot virus (PRV). A tremendous difference in fruit yield and normal growth was observed in cvs. Carifiora (A) and the $F_{1}$ hybrid (B) infected with PRV, as compared with infected cv. Sunrise Solo (C), which shows sever mosaic and stunting.

All plants of the Sunrise Solo cultivar were "productive" trees (female and hermaphrodite). Meanwhile, in the Cariflora and the $F_{1}$ hybrid only male and female trees were present, which condition reduces the amount of productive plants. In papaya production male trees are not productive. However, the extra amount of productive plants of Sunrise Solo did not compensate for the loss caused by the virus infection. Thus Cariflora and the $F_{1}$ hybrid that showed PRV tolerance produced more than the Sunrise Solo.

Sensory evaluation and chemical characteristics of fruit. Cariflora and the $\mathrm{F}_{1}$ hybrid were rated acceptable in appearance and flavor with mean values higher than 0.50 (out of a maximum of 2.00) (table 2). Papaya cultivars did not exhibit significant differences $(P=0.05)$ in their sensory attributes. The Sunrise Solo cultivar was not sensory - and chemically-evaluated because of poor appearance and heavy PRV damage of the fruit.

There was little variation in $\mathrm{pH}$ and acidity of Cariflora and $\mathrm{F}_{1}$ hybrid samples evaluated at the green ( 10 to $25 \%$ yellow) and ripe stages 


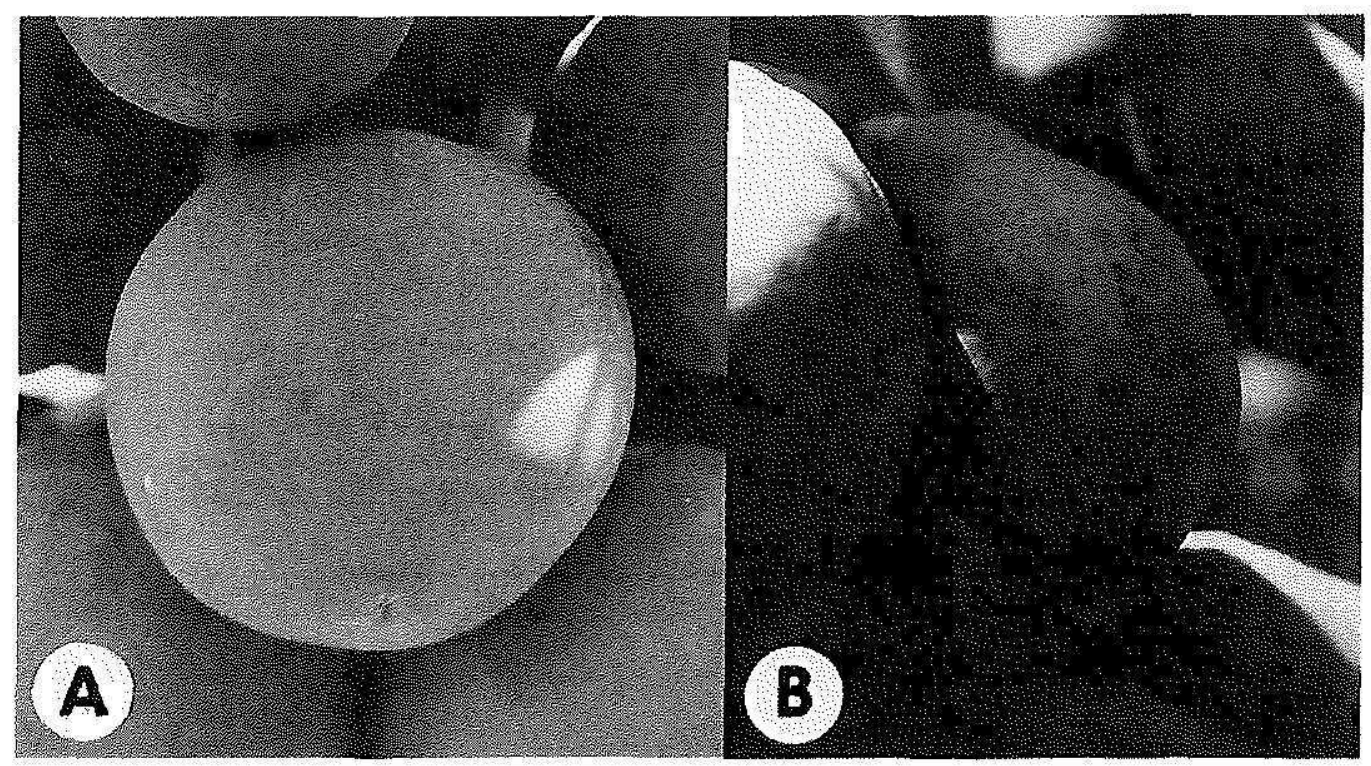

FIs. 2. Infected papaya fruits: (A) Carifiora fruit, tolerant to PRV. (B) Symptoms of PRV infection on Sunrise Solo fruit.

(75 to $100 \%$ yellow; table 3,4 ). At the ripe stage, Brix values tended to increase in both Cariflora and the $\mathrm{F}$, hybrid.

It was observed that $\mathrm{L}$ values (color from black to white) increased from the ripe to green stage (table 3,4 ). Values for "a" index (color from green to red) increased from the green to ripe stage; "b" values (from blue to yellow) followed a similar trend.

Virus inoculated on test plants. PRV was mechanically transmitted to healthy seedlings of Carica papaya, Chenopodium quinoa and Cucumis melo. Leaves of $C$. papaya presented a systemic mottling 12 days

TABLE 2.-Sensory evaluation of Cariflora papaya and $F$, hybrid.

\begin{tabular}{lcccccc}
\hline & \multicolumn{4}{c}{ Mean Values $^{2}$} \\
\cline { 2 - 7 } Samples: $^{2}$ & \multicolumn{2}{c}{ Appearance $^{3}$} & \multicolumn{2}{c}{ Flavor $^{3}$} & \multicolumn{2}{c}{ Preference $^{2} \%$} \\
\cline { 2 - 7 } & March & April & March & April & March & April \\
\hline Cariflora & 1.00 & 1.16 & 0.67 & 1.53 & 50.0 & 52.6 \\
F, Hybrid & 1.41 & 1.32 & 0.59 & 1.26 & 0.0 & 26.3 \\
& & & & & 50.0 (more) & 21.1 (more)
\end{tabular}

${ }^{1}+2,-2$ scale: $+2=$ very acceptable $;+1=$ acceptable; $0=$ questionable; $-1=$ slightly unacceptable; $-2=$ not acceptable.

"Cultivar Sunrise Solo not included.

"Average of two evaluations. 


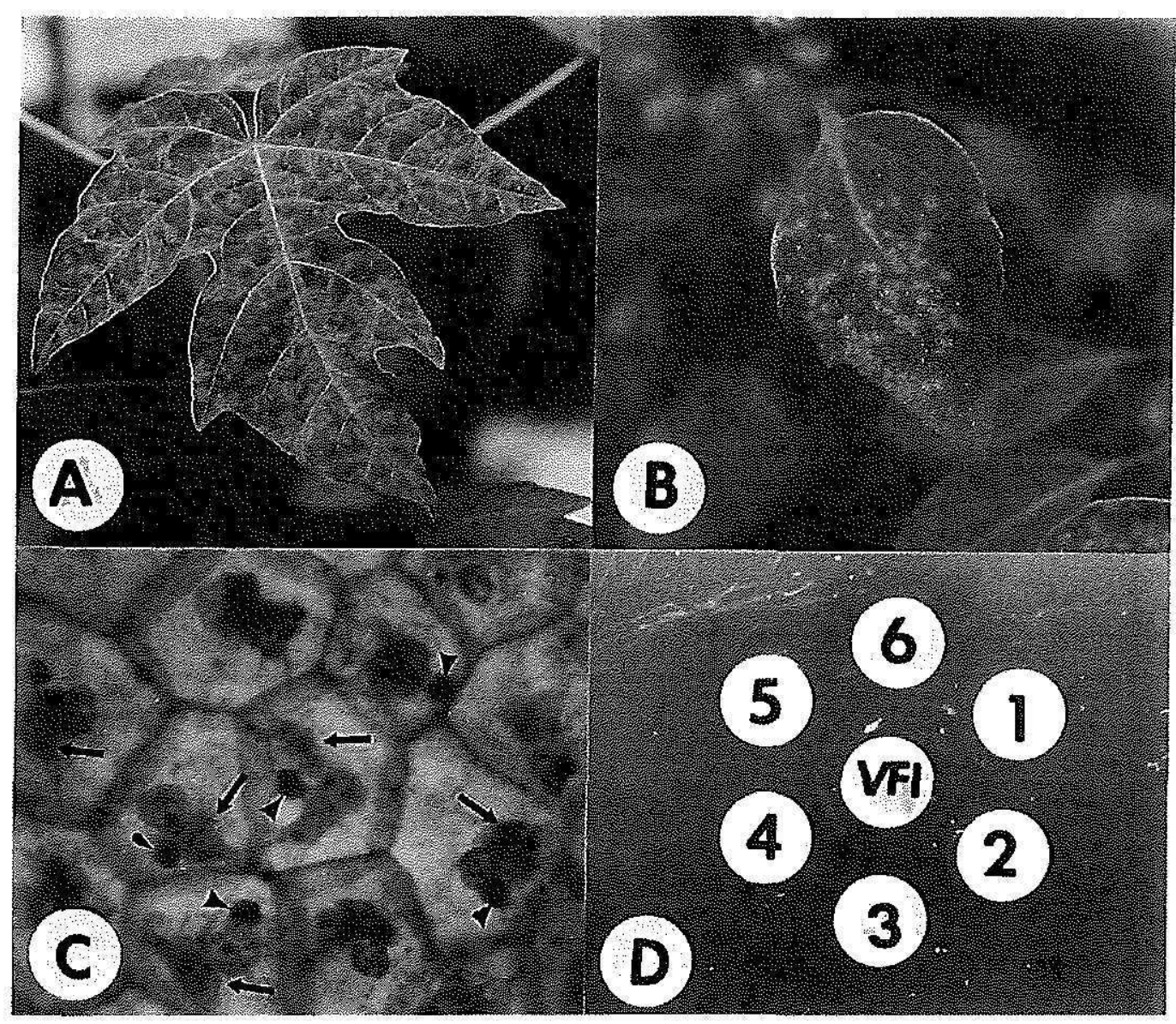

FlCx. 3. Identification of papaya ringspot virus (PRV): A-B Mechanical Inoculation. (A) Papaya leaf affected with PRV. (B) Chlorotic local lesions incited by PRV on inoculated leaf of Chenopodium quinoa. (C) Epidermal strip cells from papaya leaf affected with PRV. Arrow's indicate cylindrical inclusions and arrowheads indicate amorphous inclusions typical of PRV. (D) Outcherlony agar immunodiffusion test with PRV. The center well contained antiserum to an isolate of PRV from Florida $\left(V_{F}\right)$. The peripheral wells were filled as follows: (1 and 5) Sap containing Florida PRV. (2 and 4) Sap containing Puerto Rican PRV. (3 and 6) Healthy papaya leaf extract.

after inoculation (fig. 3A). This mottling was followed by a severe malformation of the leaves. Inoculated leaves of $C$. quinoa developed a chlorotic local lesion (fig. 3B). Infected plants of C. melo developed a mild vein clearing on their leaves. No symptoms were observed in Citrilus lanatus and Luffa aegyptiaca.

Transmission by insects. The aphis $A$. criticola was an efficient vector of PRV. Ten days after transmission all the plants developed vein clearing, followed by mosaic of the new leaves.

Light microscopy. Examination by light microscopy of infected papaya tissues revealed inclusions in the cytoplasm of epidermal cells. The cylindrical and amorphous inclusions observed were similar to those described previously for PRV (3) (fig. 3C). 
TABLE 3.-Chemical analysis of Cariflora papaya and hybrid harvested in. March 1990.

\begin{tabular}{|c|c|c|c|c|c|c|c|}
\hline \multirow[b]{2}{*}{ Sample! } & \multirow{2}{*}{$\begin{array}{l}\text { State of } \\
\text { maturity }\end{array}$} & \multirow[b]{2}{*}{${ }^{\circ}$ Brix } & \multirow[b]{2}{*}{$\mathrm{pH}$} & \multirow{2}{*}{$\begin{array}{c}\text { Acidily } \\
\%\end{array}$} & \multicolumn{3}{|c|}{ Color } \\
\hline & & & & & $\mathrm{L}$ & a & b \\
\hline & Green & & & & & & \\
\hline Cariflora & (10\% yellow) & 10.6 & 5.28 & 0,09 & 51.59 & 19.55 & 30.64 \\
\hline & Green & & & & & & \\
\hline$"$ & (25\% yellow) & 12.2 & 5.44 & 0.08 & 53.39 & 20.34 & 31.86 \\
\hline & Ripe & & & & & & \\
\hline$"$ & (100\% yellow) & 16.1 & 5.26 & 0.13 & 44.07 & 28.87 & 27.54 \\
\hline & Green & & & & & & \\
\hline $\mathrm{F}_{1}$ & (10\% yellow) & 12.0 & 5.25 & 0.06 & 56.83 & 16.41 & 32.21 \\
\hline$"$ & $\begin{array}{c}\text { Green } \\
\text { ( } 25 \% \text { yellow) }\end{array}$ & I3.0 & 5.36 & 0.08 & 54.55 & 25.25 & 32.85 \\
\hline$"$ & $\begin{array}{c}\text { Ripe } \\
\text { (100\% yellow) }\end{array}$ & 13.5 & 5.33 & 0.11 & 44.76 & 26.40 & 27.73 \\
\hline
\end{tabular}

'Cultivar Sunrise Solo not included.

Serology. Precipitin reactions between PRV isolates from Puerto Rico and Florida were obtained when tested against PRV antiserum from Florida. In crude sap from healthy papaya or with normal serum no reaction was observed (fig. 3D).

In our study high tolerance to a Puerto Rico isolate of PRV was observed in Cariflora and $F_{1}$ hybrid. Fruit yield and quality of Cariflora

TABLE 4,-..Chemical analysis of Cariflora popaya and hybrid harvested in April 1990.

\begin{tabular}{|c|c|c|c|c|c|c|c|}
\hline \multirow[b]{2}{*}{ Sample' } & \multirow{2}{*}{$\begin{array}{l}\text { Stage of } \\
\text { maturity }\end{array}$} & \multirow[b]{2}{*}{${ }^{\circ}$ Brix } & \multirow[b]{2}{*}{$\mathrm{pH}$} & \multirow{2}{*}{$\begin{array}{c}\text { Acidity } \\
\%\end{array}$} & \multicolumn{3}{|c|}{ Color } \\
\hline & & & & & $\mathrm{L}$ & a & b \\
\hline & Green & & & & & & \\
\hline Cariftora I & (10\% yellow) & 10.6 & 5.26 & 0.12 & 54.28 & 20.70 & 31.94 \\
\hline & Green & & & & & & \\
\hline$"$ & (50\% yellow) & 13.3 & 5.24 & 0.14 & 48.12 & 25.73 & 29.37 \\
\hline$\therefore$ & $\begin{array}{c}\text { Green } \\
\text { (75\% yellow) } \\
\text { Green }\end{array}$ & 12.1 & 5.21 & 0.14 & 54.05 & 27.15 & 32.49 \\
\hline $\mathrm{F}$ & $\begin{array}{c}\text { (10\% yellow) } \\
\text { Green }\end{array}$ & 12.5 & 5.26 & 0.10 & 51.48 & 20.09 & 30.17 \\
\hline " & $\begin{array}{c}\text { (50\% yellow) } \\
\text { Green }\end{array}$ & 12.9 & 5.28 & 0.13 & 47.85 & 24.84 & 2.9 .28 \\
\hline " & (75\% yellow) & 14.0 & 5.14 & 0.11 & 49.54 & 29.67 & 30.63 \\
\hline
\end{tabular}

'Cultivar Sunrise Solo not included. 
and $\mathrm{F}_{1}$ hybrid cultivars were better than those of the commercial cultivar Sunrise Solo after being virus inoculated.

Cariflora and the $\mathrm{F}_{1}$ hybrid papayas are potentially suitable for commercial planting in Puerto Rico. Both bear small spherical fruits of approximately $14.0 \mathrm{~cm}$ with moderately firm flesh, well suited for handling and packing. Both cultivars have acceptable fruit quality characteristics. Their fruits have sweet yellow to pale orange flesh with acceptable taste and aroma.

In this study, Cariflora was able to effectively transmit PRV tolerance characteristic to Sunrise Solo in the F, hybrid. However, in this case the $F$, hybrid lacks the hermaphrodite type, and thus there are fewer productive trees in the field. In order to improve $F_{1}$ hybrid characteristics and papaya production in Puerto Rico, further research is needed toward developing hermaphrodite plants in the $F_{1}$ hybrid by crossing a Cariflora female with a Sunrise Solo hermaphrodite.

\section{LITERATURE CITED}

1. Agric. Exp. Sta., 1989. Conjunto Tecnologico para la Producción de Papaya. Univ. P.R.

2. Arriola, M.C., J.F. Calzada, J. F. Mencgu, C. Rols and Garcia, 1980. Papaya-Tropical and Subtropical Fruits. The AVI Publishing Company, Inc.

3. Christie, R.C. and J.R. Edwardson, 1977. Light and electron microscopy of plant virus inclusions. Fla. Agric. Exp. Sta. Monogr. Sex. 9, 155 pp.

4. Conover, R.A., 1964. Distortion ringspot, a severe disease of papaya in Florida. Proc. Fla. State. Hort. Soc. 77: 440-444.

5. _ and R.E. Lutz, 1978. Progress in breeding papayas with tolerance to papaya ringspot virus and papaya mosaic virus. Plant Dis. Rep. 54: 893-895.

6. —- - and S.E. Malo, 1986. 'Cariflora'-a papaya ringspot virus-tolerant papaya for South Florida and the Caribbean.

7. Cook, A.A. and F. W. Zettler, 1970. Susceptibility of papaya cultivars to papaya ringspot virus and papaya mosaic virus. Plant Dis. Rep. 54: 893-895.

8. Departamento de Agricultura, 1989. Estadisticas agrícolas. Ingreso agrícola: Cifras revisadas para 1987-88 y preliminares para 1988-89.

9. Herold, F. and J. Weibel, 1962. Electron microscopy demonstration of papaya ringspot virus. Virology 18: 307-311.

10. Jensen, D.D., 1949. Papaya ringspot virus and its vector relationships. Phytopathology 39: 212-220.

11. Lana, H.F., 1980. Transmission and properties of virus isolated from Carica papaya in Nigeria. J. Hort. Sci. 55: 191-197.

12. Larmond, E., 1977. Laboratory methods for sensory evaluation of food. Canada Dept. Agric. Research Brand, Publ. 1637.

13. Ochima, N., 1975. The control of tomato mosaic disease with attenuated virus of tomato strain of TMV. Rev. Plant. Prot. Res. 8: 126-135.

14. Puerto Rico Planning Board, 1987. 1986 External Trade Statistics of Puerto Rico.

15. Purcifful, D.E., 1972. Papaya ringspot virus. No. 84: Description of plant viruses. Commonw. Mycol. Inst., Assoc. Appl. Biol. Kew, Surrey, England. 
J. Agric. Univ. P.R. VOL. 78, NO. 3-4, JuLY/OCTOBER 1994121

16. - and D.L. Batchelor, 1977. Immunodiffusion test with sodium dodecyl sulfate (SDS) treated plant viruses and plant, viral inclusions, IFAS, Agric. Exp. Sta., Fla. Univ. No. 788, 39 pp.

17. Rodríguez, R.L., 1978. La virosis de la papaya (Carica papaya L.) en Puerto Rico. M.S. Thesis. Univ. P. R., Mayaguez. 54 pp.

18. Singh, A.B., 1969. A new virus disease of Carica papaya in India. Plant Dis. Rep. 53: $267-269$.

19. Story, G.E. and R.S. Halliwell, 1969. Identification of distortion ringspot virus disease of papaya in the Dominican Republic. Plant Dis. Rep. 53: 757-760.

20. Yeh, S.D., D. Gonsalves, H.L. Wang, R. Namba and R.J. Chiu, 1988. Control of papaya ringspot virus by cross protection. Plant Disease 72(5): 375-380. 